\title{
The Trend Toward Academic Recognition of College Librarians
}

\author{
Mr. Carlson is director of libraries, Oregon \\ State System of Higher Education.
}

$\mathrm{L}$

IBRARIANSHIP has, within the past half century, made a definite and on the whole heartening advance toward the status of a true educational profession. This is a conviction I have long held, and one which, it seems to me, cannot be escaped by anyone who has followed the events and the literature of librarianship for the past quarter century. For me it is a conviction that has been strengthened, as a result of my preparation, within the past year, of a defense of the present and long held academic status of the librarians of the Oregon State System of Higher Education.

In gathering background, facts, and opinions to refute the proposal of the Oregon State Civil Service Commission that our system librarians should be removed from the academic staffs of our several institutions and assigned civil service status I found it necessary to review the literature bearing on the contributions which college and university librarians have made to the instructional and research programs of their institutions and the way in which these contributions have been and are recognized. I found, as I had expected, that the roots of the college librarian as an important and recognized member of the academic team go deep, and that the academic contributions of college librarians are increasing in depth and stature. That this is being recognized, more and more, by higher educational institutions and by educational societies, associations, and accrediting agencies is shown by college library standards and writings of the past three decades, including more recently the articles of Lundy, Thompson, and Downs. We have now, I believe, reached a point where a summary of the trend toward recognition of the academic contributions of college librar- ians, and the attendant assignment of faculty status and rank, may be useful.

\section{Evolution of College and University \\ LIBRARIES AND LIBRARIANSHIP}

It has only been in the last one hundred years that the college and university library has emerged as a fundamental teaching and research instrument. Corollary with this development college and university librarianship has necessarily evolved to a corresponding extent, with an increasingly sharply defined distinction between the clerical processes of library work and its professional aspects. As a result the modern college and university librarian must be possessed of scholarly instincts and aptitudes, have a wide range of competence in foreign languages, an extensive knowledge of the literature and subject matter of highly technical fields, a complete understanding of the research processes, including organizational mastery over a vast literature, an extensive knowledge of foreign book markets and dealers and of international developments in cultural affairs, familiarity with higher educational problems and trends and an ability to transmit research and subject knowledge to students, undergraduate and graduate, and to faculty members. All this of course requires advanced academic degrees to an extent which was not found, nor generally required, in the early college or university.

In earlier days college and university librarians, even those of scholarly backgrounds and with advanced degrees, personally performed many of the numerous clerical details incidental to operation of their libraries. This perhaps accounts for the somewhat prevalent but disappearing concept of college librarianship as a non-scholarly and largely routine activity. Contrary to this concept the college or university librarian who is solely a biblio- 
graphical housekeeper has definitely disappeared from all well-administered colleges and universities to be replaced by librarians of high scholarly qualifications who are required to make fundamental and integral contributions to the teaching and research programs of their institutions. This statement is completely substantiated by the history of higher education and the literature of librarianship.

As early as 1876 Professor Otis Robinson of the University of Rochester, writing in - the first volume of the Library Journal, said this:

\begin{abstract}
A librarian should be much more than a keeper of books; he should be an educator ... relation ... ought especially to be established between a college librarian and the student readers. No such librarian is fit for his place unless he holds himself in some degree responsible for library education of the students ... it is his province to direct very much of their general reading; and especially in their investigation of subjects he should be their guide and their friend. ${ }^{1}$
\end{abstract}

In 1898 when the first professional school of librarianship was just beginning to establish a firm hold on life, President Daniel Goit Gilman of Johns Hopkins University, certainly one of the most influential of American educators, recognized the importance of the college librarian in these words:

The librarian's office should rank with that of professor... The profession of librarian should be distinctly recognized. Men and women should be encouraged to enter it, should be trained to discharge its duties and should be rewarded, promoted and honored in proportion to the services they render. ${ }^{2}$

Mr. W. E. Henry, one of the pioneer leaders of the library profession in the Northwest and founder of the University of Washington Library School, was also among the educators who early recognized both the teaching functions of college librarians and that they earn and deserve faculty status. This is what he said in I9II:

The library assistant is not usually a teacher in the sense of a hearer of recitations or a formal lecturer, yet anyone who knows his real work must admit that it is frequently as personal and quite as scholastically helpful

1 As quoted by Samuel Rothstein, Library Quarterly, $23: 7$, January, I 953. Library, 2d ed., New York, Wilson, 1949. p. 277. as that done by the teacher. If this equality does not exist then the staff should be revised. With such preparation and such relationship to the educational processes I shall claim that the library staff must rank with the faculty or teaching staff of any department. ..3

In introducing the landmark study by George Alan Works, College and University Library Problems, published in 1927, and based on personal visits to and detailed study of a large number of college and university libraries, Samuel P. Capen, then Chancellor of Buffalo University, begins thus:

Since the beginning of the twentieth century American colleges and universities have undergone an essential transformation. . . The body of knowledge with which higher institutions are called upon to deal has been vastly augmented. The natural sciences have had an especially rapid development. New methods both for creating and imparting knowledge in these fields have been devised. ... To meet these new demands in pure and applied sciences, universities have spent immense sums for laboratories and apparatus. . . Undergraduate instruction in the humanities has likewise been radically modified. The single textbook has given way to a wide range of reference material and the increasing output of scholars tends to make existing materials quickly obsolete. Most important of all, graduate instruction and research are no longer mere by-products. They have become a major activity of universities, involving nearly all the members of the teaching staffs and a rapidly growing body of mature students. It is obvious that these changes have completely altered the position of the university or college library. Demands are now made upon it that twentyfive years ago were unknown. ${ }^{4}$

How extensive the implications of the changing nature of higher education have been for college libraries Works' study revealed. $\mathrm{He}$ found that while the head librarian was usually given faculty rank and status that "too many" faculty members and administrat ve officers were prone to think of the remainder of the staff as discharging responsibilities essentially clerical in nature. He noted that while there is much such work in libraries, the

${ }^{3}$ Henry, W. E. "Academic Standing of College Library Assistants and their Relation to the Carnegic Foundation," ALA Bulletin, 5:261-63, July, 19I I.

${ }_{4}$ Works, George Alan. College and University $L i$. brary Problems. Chicago, American Library Association, 1927. p. v. 
activities of the librarians called for a greater breadth of scholarship and a much longer period of professional preparation than is required for clerical positions. In this connection he said:

The recognition of the titular librarian as a member of the faculty may have been an adequate method of dealing with the situation a generation ago when the staff in many institutions consisted of a librarian and a relatively untrained staff. It is entirely inadequate when a body of professional workers is developed such as was found to constitute a considerable proportion of the staffs of the libraries included in this study. In a substantial proportion of library positions this procedure will not bring to the library the type of personnel that can give the service expected by students and faculty. This condition should have more consideration than it has been given by university executives. ${ }^{5}$

That college and university administrators have, as recommended by Works, been giving serious and constructive attention to the duties of their librarians, as well as their qualifications, is shown by the fact that the doctor's degree in librarianship, which was unknown when Works made his study, is now increasingly found on the library staffs of colleges and universities, along with other advanced degrees. It is no accident that of the relatively few persons who have acquired the doctor's degree in librarianship since 1930, nearly all are to be found in the colleges or universities. Neither is it an accident that before the availability of doctoral graduates from library schools, and since then to some extent, colleges and universities have sometimes gone outside the library field to find, as their librarians, persons with advanced academic degrees.

"The time has definitely passed," say Randall and Goodrich in their Principles of College Library Administration, "when the same course of study will fit a man for librarianship in any sort of a library. The librarianship of a college library requires certain special training, particularly along lines which will enable the student to fit his library into the educational process." 6 The truth of this statement is emphasized by the fact that we now

Ibid. p. ${ }^{82-83}$. ${ }^{-}$Randall, Wiliam and Goodrich, Francis L. Principles of College Library Administration. $2 \mathrm{~d}$ ed., Chicago, University of Chicago Press and American Library Association, I94I. p. I 21-22. have in colleges and universities, science librarians, chemistry librarians, engineering librarians, art librarians, pharmacy librarians, social science librarians, humanities librarians, custodians of map collections, custodians of special collections, and librarians with numerous other specialties. These librarians must not only know and understand library methods and procedures. They must, in addition, be at home in their subject fields, meet faculty members in these subject areas on an equal footing and be completely familiar with and understand the terminology and the bibliographical practices of a highly specialized literature. Librarians of this kind are increasingly sought by colleges and universities and, fortunately, are being increasingly found.

Another landmark in the literature of librarianship, Harvie Branscomb's Teaching with Books, which is devoted entirely to the teaching functions of college and university libraries, leaves no room for doubt that college libraries are primarily a teaching instrument and that those who work in them, at the professional level, play a direct and vital part in the teaching process. Branscomb, who is now chancellor of Vanderbilt University, strongly emphasizes the necessity of improving the status of the librarian to equal, where this situation is not found, that of his faculty colleagues. Others who have written forcefully and authoritatively on the teaching function of the college library are Dr. Henry Wriston, president of Brown University and Dr. William Warner Bishop, for many years the eminent librarian of the University of Michigan.

Guy R. Lyle, in The Administration of the College Library, shows that in 1939, twelve years after the Works study, academic status was, in more than $50 \%$ of a group of institutions queried by Mrs. Miriam Maloy, accorded to library staff members holding the more important positions. Even the lesser positions, Mrs. Maloy found, were given academic rank in $40 \%$ of the institutions. By 1948 a study of southern institutions, as reported by Lyle showed that in $65 \%$ of the universities studied all professional staff members had faculty status; in a group of college libraries $56 \%$ of all the professional staff had faculty status while in the teachers colleges 90\% was found to have such status. ${ }^{7}$ Further evidence of the trend toward academic rank

${ }^{7}$ Lyle, Guy R. op. cit., p. 276-80. 
and professional status is the study by Lawrence S. Thompson published in Library Trends, July 1952. The Thompson article confirms an extension of academic status for librarians at an increasing number of institutions. $^{8}$

Concrete evidence of the assignment of faculty status to librarians in a wide range of institutions is found in the U. S. Office of Education Circular, no. 370, March 1953, which, among other things shows the academic status of librarians at the institutions included. Twenty-seven of the institutions listed assign academic status to all their librarians and many others do so on a partial basis. This list is by no means complete and many institutions, such as Oregon State College and Oklahoma A.\&M., which give academic status to their librarians are not included in it. When Works made his study in 1927 it is highly probable that not a single institution listed in Circular no. 370 was assigning faculty status to any member of the library staff other than the head librarian.

While it is still possible to find a good many colleges and universities which do not assign faculty status to their librarians, such institutions are, as the literature and current trends conclusively demonstrate, becoming progressively fewer. Of one thing we can be absolutely certain. No reputable and welladministered higher educational institution can be found which would maintain that its librarians, regardless of the status it assigns to them, do not make significant contributions to the teaching and research program. Once this is granted then there seems no valid or just reason for assigning a semi-clerical status to them. Certainly librarians qualify for academic status as readily as numerous other nonteaching staff members such as editors, deans of students, athletic coaches, student counselors, state extension workers and full time research workers, all of whom are quite generally accorded full academic status and rank by educational institutions.

\section{Library StandardS OF EdUCational Associations and Foundations}

The increasing importance of libraries in higher education is reflected by the high standards, far above anything required in the early

8 Thompson, Lawrence S. "Preparation and Status of Personnel," Library Trends, I:95-103, July I952. part of this century, which are being set for them. In 1928, when the Carnegie Corporation embarked on an extensive and ambitious program to strengthen the college libraries of this nation it was, of course, concerned that the large sums of money it planned to devote to college library purposes would be effectively used. It therefore constituted an Advisory Group on College Libraries, charging it with the responsibility of a careful study of college libraries and formulation of advisory recommendations covering all phases of the development and operation of them. The work of this Advisory Group constitutes still another landmark in college librarianship. Included in its College Library Standards, published in 1932 and which formed the basis for grants to 8I colleges totaling $\$ 96 \mathrm{r}, 000$, are these pertinent recommendations relative to the library staff:

In view of the importance of the services rendered by the library staff, its members should receive adequate recognition in the academic community with respect to salary scales, standards for advancement, security of tenure, etc. . . The college librarian should have administrative power covering the entire library organization, and should be responsible directly to the administrative head of the college. He should be considered as a member of the educational staff of the college.

The Northwest Association of Secondary and Higher Schools, makes this statement in its Revised Manual of Accrediting Higher Schools, 1946:

Staff: The librarian shall be a full-time staff member with a degree from a library school and shall have faculty rank and salary status. There shall be such other members of the staff as are necessary for the efficient administration of the library.

The Division of Nursing Education of the National League of Nursing in its Guide to the Development of Libraries in Schools of Nursing, 1952, has the following statement:

The librarian has faculty rating, with corresponding salary, obligations and privileges, which ensures attendance at nursing conferences, classes, and demonstrations of nursing care, and participation in discussions bearing on the development of teaching programs in the school.

The Southern Association of Colleges and 
Secondary Schools, in a report published in 1947, makes the following detailed recommendations relative to the functions of the college and university library and its staff:

Relation of the Library to Instruction: During the past two decades, the major interest in college libraries has been in their growth, in suitable buildings, and in librarians technically trained. At present, the prime concern of college teachers, librarians, and administrators is in the effective integration of the library with the teaching processes. The achievement of such integration calls for a clarification of the functions of the college library and for continuous planning and cooperation on the part of the administration, faculty, and a qualified library staff.

The Library Staff:

The Library Staff should be adequately trained, not only technically, but academically. This is essential to effective cooperation on a basis of mutual understanding and respect with faculty in instruction and in the promotion of the cultural development of students.

A. The library staff should be encouraged

I. To take courses while employed in order to round out their academic and professional education;

2. To take leaves for advanced study ;

3. To participate in professional library organizations;

4. To contribute to library and educational literature;

5. To read widely in general and professional fields.

B. The librarian and his professional assistants should enjoy such academic status and administrative relations as will make them most useful to the institution. Toward this end, the librarian should be invited to serve on committees concerned with instruction.

The Classification and Pay Plans for Libraries in Institutions of Higher Education, published by the American Library Association in 1947, makes the following statement relative to the educational responsibilities and academic status of college and university librarians:

As all professional staff members contribute to the educational program of the institution they are deemed to be of an academic rank corresponding to deans, teaching staff, and departmental assistants. They should also enjoy the academic privileges including participation in retirement plans.
The Academic Contributions of Acquisition and Cataloging Librarians

We found, in the defense of the academic status of our Oregon system librarians that even prejudiced laymen did not find it too difficult to appreciate the educational and research contributions and functions of public service librarians. It was difficult for such persons, however, to understand how an order librarian, a serials librarian or a cataloger, working entirely behind the scenes, could be an integral and significant part of the teaching and research process. These are some of the arguments we advanced in support of our contention that all the professional librarians of a modern college or university contribute to the teaching and research their institutions do.

The first and basic step in building a higher educational library is to decide what books, journals, maps, pictures, films, and recordings should be in the library. These decisions, in a college or university, are arrived at jointly by the acquisition librarians and faculty members, working cooperatively to gather those materials which will fully support the educational and research programs of their institutions. This is far more than a passive acceptance by the librarians of faculty recommendations. Extensive materials are added on the independent and scholarly judgement of the librarians. Obviously these processes require, on the part of acquisition librarians, a comprehensive knowledge of the entire range of scholarly literature in practically every field of intellectual endeavor. They also require harmonious working and a close acquaintanceship with members of the faculty, as well as an understanding of the teaching and research objectives of our institutions.

The all-inclusive nature of modern higher education is such that the materials needed in libraries must be drawn from all over the world and in a great variety of languages. This, of course, requires a working knowledge, on the part of acquisition librarians, of many languages, and familiarity with widely ranging trade and national bibliographies of the leading countries of the world, as well as of indexes and bibliographies in highly specialized subject literatures. Once having made the essential research contribution of finding and identifying needed literature, acquisition librarians must then administer the necessary purchasing processes. To do this efficiently 
they must have an extensive knowledge of the book markets of the world, familiarity with foreign dealers, knowledge of foreign exchanges. They must also follow careful ordering procedures, with a correct use of the various languages. Without the fundamental and necessary work of this kind by acquisition librarians, in close collaboration with faculty members, the modern research university library could not exist. There can be no doubt then that acquisition librarians are important keystone contributors to the teaching and research of the modern university.

The catalogers of a college or university stand between the acquisition and serials librarians busily operating their dragnets to draw material from all parts of the world into the library and the service librarians whose functions it is to interpret and make easily available the totality of the library's holdings. It is the duty of catalogers to reduce to order and system a vast miscellany of materials flowing into the library, on almost every conceivable subject and from all over the world. These materials, arriving in complete subject confusion, the carefully wrought ministrations of the catalogers organize into easy findability. To do this satisfactorily, in a college or university, requires familiarity with the teaching and research program of the institution, an awareness of scholarly research trends and developments and a continuing introduction into the catalog of new scholarly terminology, as well as the elimination or revision of obsolete or outmoded terms. All this requires knowledge of scholarly and scientific subjects.

Catalogers sit at the fount, as it were, of the productivity of the human mind, reducing all to order and system. Working at the frontiers of knowledge they see and help to order its unfolding. While materials come to them in quantity they cannot be handled in quantity. Each book and pamphlet must be considered and handled as a separate entity and its content, regardless of language, sufficiently mastered to classify it satisfactorily both by numbers, and verbally by subject headings, and to describe it so accurately that it becomes a unique bibliographical item which cannot be confused with the millions of other books in the world. Fundamentally this is an intellectual process, sometimes, in matters of principles and policies, profoundly so, and it is for this reason that persons of scholarly bent make the best catalogers.

By what the catalogers do in their daily work of absorbing new titles, and of eliminating outmoded subject terminology in favor of current usage, the research program of the college and university is squarely buttressed. Anyone who maintains otherwise fails to understand and appreciate the extensive and complex bibliographic machinery upon which the modern scholarly world rests. Catalogers who fashion and maintain the intricate bibliographical machinery necessary for operation of our libraries are indeed, in the most basic sense, important contributors to the teaching and research processes. Without their services higher educational institutions could not function at all either as teaching or as research agencies.

\section{SUMMARY}

The literature and the standards of accrediting agencies, as here briefly summarized, the inescapable and important function of the library in present day instruction and research, the increasing recognition of the library and librarians by educational associations and societies, and by individual educators, all these indicate that librarians are surely, although some of us may think too slowly, moving from their semi-clerical status of thirty years ago toward full acceptance as members of the academic family. Certainly we have reached a point, as R. B. Downs has so pungently noted, ${ }^{9}$ where a chief librarian can no longer with easy conscience accept faculty rank and academic status for himself, leaving his staff in a vague kind of academic no-man's-land between the faculty and the clerical staff.

Downs, R. B. "Are College and University Librarians Academic?" COLLEGE AND RESEARCH LIBRARIES, I 5 : I 2, January, I 954.

\section{Five Year Index}

A Five-Year Index covering volumes II-15 (1950-1954) will appear in the April issue of COLLEGE AND RESEARCH LIBRARIES. 